\title{
Endoparasites of red fox (Vulpes vulpes) in the Slovak Republic with the emphasis on zoonotic species Echinococcus multilocularis and Trichinella spp.
}

\author{
M. MITERPÁKOVÁ, Z. HURNÍKOVÁ, D. ANTOLOVÁ, P. DUBINSKÝ
}

Parasitological Institute of the Slovak Academy of Sciences, Hlinkova 3, 04001 Košice, Slovak Republic,

"E-mail: miterpak@saske.sk

\begin{abstract}
Summary
Due to specific geographical localization, climatic and geomorphologic conditions, several serious parasitic diseases circulate in the territory of the Slovak Republic that makes this area an ideal model territory of the central European red fox system. The red fox is an important reservoir host of parasites, which can be spread to another animals and humans. Our study was aimed at determining the current prevalence of certain parasites in red foxes from the entire territory of the Slovak Republic and identifies some ecological factors influencing their epidemiology. Within the first systematic investigation of red foxes carried out between the years 2000 and 2006 in total 4026 foxes were examined for Echinococcus multilocularis (prevalence $31.1 \%$ ) and 4699 foxes were investigated for the presence of Trichinella spp. larvae (10.4\% infected). The results of the next separate study revealed that $83.3 \%$ of 1198 red foxes in the Slovak Republic had coccidian oocysts and helminth eggs in their faeces. Fifteen helminth species including two trematode, four cestode and nine nematode species were detected by coprological examination. Nine of these parasite taxa have zoonotic potential: Capillaria spp. (prevalence $22.4 \%$ ), Ancylostoma caninum (18.1\%), Toxocara canis (12.5\%), Taenia spp. (12.2\%), Mesocestoides spp. (5.8\%), Strongyloides stercoralis (1.6 $\%)$, Hymenolepis diminuta (0.6\%), Dipylidium caninum $(0.4 \%)$ and Opisthorchis felineus $(0.3 \%)$. Toxascaris leonina was the most common helminth species found in this survey $(42.9 \%)$.
\end{abstract}

Key words: parasite; red fox; Echinococcus multilocularis; Trichinella spp.

\section{Introduction}

The red fox (Vulpes vulpes) is the most abundant wild carnivore living in the Slovak Republic. The distribution and density of the red foxes has increased dramatically over the last decade as a consequence of oral antirabies vaccination (Švrček et al., 2000). The population of red foxes increased from 6154 in 1993 to 13331 in 1996 (Statistical Yearbook of the Slovak Republic, 1994, 1997). Since 2000, more than 20000 red foxes have been hunted annually in Slovakia. From the veterinary point of view, foxes represent a major wildlife reservoir of zoonotic parasites transmissible to humans and domestic animals, especially in rural areas. The increasing population of red foxes and also the first finding of Echinococcus multilocularis in the Slovak Republic (Dubinský et al., 1999) has underlined the importance of the red fox as a source of zoonotic infectious diseases. Until recently, knowledge of the parasites of foxes in the Slovak Republic was limited to information collected during a few studies conducted several decades ago (Mituch, 1962, 1964, 1972; Prokopič, 1958, $1965)$ or restricted to an area of only one region (Letková et al., 2001). As the ecosystems become more fragmented and human - wildlife interactions intensify, a clear understanding of what constitutes a natural distribution of parasite species is needed. The aim of the present study was to ascertain the current status and overall prevalence of parasites in red foxes. By collecting a large sample of foxes from different regions, we have acquired an insight into the ecological factors that influence susceptibility of their populations to parasite infections.

\section{Materials and methods}

Study area

The study area was the entire territory of the Slovak Republic covering an area of $49034 \mathrm{~km}^{2}$. The country is located at the geographic centre of Europe and belongs to the moderate Atlantic-continental climatic zone. The geography is characterized by major differences in the height above sea level (the lowest point - Bodrog river: $94 \mathrm{~m}$, the highest point - Gerlach peak: $2655 \mathrm{~m}$ ), which determines 
variation in climate, vegetation, and landscape that allowed us to evaluate different host-parasite-environment interactions. Southern regions (Bratislava, Trnava, Nitra and Košice) are characterized by high mean annual air temperature $\left(10-11.5^{\circ} \mathrm{C}\right)$ and low mean annual rainfall $(430-$ $680 \mathrm{~mm}$ ). Agricultural land is the predominant landscape in this part of the country. On the other hand, the northern (Trenčín, Žilina, Prešov) and central regions (Banská Bystrica) are typified by low mean annual air temperature (5 $\left.8.8^{\circ} \mathrm{C}\right)$, high mean annual rainfall $(800-1330 \mathrm{~mm})$ and low temperature of the soil surface and high humidity of the soil. Mixed and coniferous forests and pastures occupy the largest part of this territory.

\section{Collecting and storage of the samples}

Red foxes hunted within the control of the effect of antirabic vaccination were included in this study. Animals shot by hunters were transported to the State Veterinary and Food Services for autopsy and rabies examination. Faeces, small intestines and muscle samples of individuals not infected with rabies were delivered to the Parasitological Institute for parasitological investigation. In order to reduce the infection risk, intestines and faeces were deepfrozen at $-80{ }^{\circ} \mathrm{C}$ for 7 days before the examination. To ensure representative sampling, the samples were collected from all geographical regions and the locality where the specimen was hunted was recorded.

\section{Parasitological examination}

Sedimentation and counting technique for Echinococcus multilocularis detection

In separate study a total of 4026 red fox small intestines were examined for the presence of E. multilocularis. Modified sedimentation and counting technique (SCT) using 1.5 $\mathrm{mm}$ mesh size filter was used for the parasite detection (Raoul et al., 2001). Tapeworms were identified following morphological criteria according to Vogel (1957) and Thompson (1995).

\section{Digestion method for detection of Trichinella larvae}

A minimum of $10 \mathrm{~g}$ of muscle samples from 4669 red foxes were examined individually for the presence of Trichinella spp. larvae by the artificial HCl-pepsin digestion method according to Kapel and Gamble (2000). Intensity of infection was expressed as number of Trichinella larvae per one gram of muscle samples (lpg). Larvae collected from infected foxes were identified to species level by the multiplex polymerase chain reaction (PCR). Extraction of DNA and PCR amplification was done according to Pozio and La Rosa (2003).

\section{Faecal examination}

A total of 1198 faecal specimens was collected from the rectum or colon of foxes autopsied at State Veterinary and Food Institutes. The samples were frozen and delivered to the Parasitological Institute. Faeces were investigated using standard sugar centrifugation flotation technique (the
Shaether method; Jurášek \& Dubinský, 1993). Eggs of gastrointestinal helminths and oocysts of gastrointestinal coccidia were distinguished by morphological characteristics and linear measurements according to Sloss (1970) and eggs of helminths subsequently identified do species. Coccidia could not be identified to species because freezing precluded attempts at sporulation, a necessary step prior to identification. Prevalence of individual helminth species was calculated as the ratio of the number of faecal samples infected to the total number examined.

\section{Statistical analysis}

Logistic linear regression analyses at the $95 \%$ confidence level were performed and the significance of differences in prevalence of parasite species in different regions of the Slovak Republic was evaluated by the chi-square test. Simple correlation coefficients were calculated to determine any noticeable relationships between prevalence and intensity of parasite infection and environmental factors. All statistical analyses were conducted using STATISTICA 6 Base (StatSoft, Inc., 2001).

\section{Results}

From 2000 to 2006, the small intestines of 1254 of 4026 red foxes $(31.1 \%)$ from the Slovak Republic were infected with Echinococcus multilocularis. Substantial differences in prevalence were recorded between regions, with the highest prevalence $(\geq 40.0 \%)$ in the northern part of the country, in Žilina, Prešov and Trenčín regions (Table 1). In several districts of these regions, prevalence reached $\geq 60$ $\%$. In contrast, in southern parts of Slovakia, from $12.2 \%$ (in the Bratislava region) to $25.3 \%$ (in the Nitra region) of red foxes were infected (Table 1). This particular difference was statistical significant $(\mathrm{p}<0.001 ; \mathrm{X}=252.3)$. The number of E. multilocularis found in individual foxes varied from 1 to 240000 specimens. Significant correlation was recorded between the mean annual precipitation and both prevalence of E. multilocularis $(\mathrm{r}=0.933, \mathrm{p}=0.022)$ and mean worm burden of the tapeworm in red foxes $(\mathrm{r}=$ $0.973, \mathrm{p}=0.021)$. Neither prevalence, nor mean worm burden of E. multilocularis significantly correlated to mean annual air temperature.

Table 1. Prevalence (\%) of Echinococcus multilocularis and Trichinella spp. in individual regions of the Slovak Republic in $2000-2006$

\begin{tabular}{lcc}
\hline \multicolumn{3}{c}{ Prevalence in \% $(\mathbf{9 5} \% \mathbf{C I})$} \\
\hline Region & E. multilocularis & Trichinella $\mathbf{\text { spp. }}$ \\
\hline Bratislava & $12.2(0.08-0.18)$ & $4.9(0.03-0.09)$ \\
Trnava & $14.1(0.10-0.19)$ & $1.8(0.01-0.04)$ \\
Nitra & $25.3(0.22-0.30)$ & $1.8(0.01-0.03)$ \\
Trenčín & $41.9(0.36-0.48)$ & $6.4(0.04-0.10)$ \\
Banská Bystrica & $30.8(0.28-0.34)$ & $12.4(0.10-0.15)$ \\
Žilina & $49.8(0.45-0.54)$ & $9.1(0.07-0.12)$ \\
Prešov & $40.4(0.37-0.44)$ & $14.8(0.13-1.17)$ \\
Košice & $18.6(0.16-0.21)$ & $17.6(0.15-0.20)$ \\
\hline Slovak Republic & $\mathbf{3 1 . 1}(\mathbf{0 . 2 9}-\mathbf{0 . 3 3})$ & $\mathbf{1 0 . 4}(\mathbf{0 . 0 9}-\mathbf{0 . 1 1})$
\end{tabular}


Table 2. Parasites diagnosed in faeces of red foxes in individual geographical regions of the Slovak Republic

\begin{tabular}{|c|c|c|c|c|c|c|}
\hline \multicolumn{7}{|c|}{ Number of positive foxes/Prevalence (\%) } \\
\hline $\begin{array}{c}\text { Surveyed region } \\
\text { (administration units) }\end{array}$ & $\begin{array}{c}\text { South-western } \\
\text { (Bratislava, Trnava, } \\
\text { Nitra) }\end{array}$ & $\begin{array}{l}\text { North-western } \\
\text { (̌̌ilina, Trenčín) }\end{array}$ & $\begin{array}{c}\text { Central } \\
\text { (Banská Bystrica) }\end{array}$ & $\begin{array}{c}\text { North - eastern } \\
\text { (Prešov) }\end{array}$ & $\begin{array}{l}\text { South - eastern } \\
\text { (Košice) }\end{array}$ & $\begin{array}{c}\text { Slovak } \\
\text { Republic } \\
(95 \% \text { CI }) \\
\end{array}$ \\
\hline $\begin{array}{l}\text { Climate region/Mean } \\
\text { annual air temperature }\end{array}$ & $\begin{array}{c}\text { warm, very dry } \\
/ 9-12^{\circ} \mathrm{C}\end{array}$ & $\begin{array}{c}\text { moderately cool, } \\
\text { humid-very humid } \\
/ 4-8{ }^{\circ} \mathrm{C}\end{array}$ & $\begin{array}{c}\text { warm-moderately } \\
\text { cool, moderately } \\
\text { humid } / 8-9^{\circ} \mathrm{C} \\
\end{array}$ & $\begin{array}{c}\text { moderately warm- } \\
\text { cool, moderately } \\
\text { humid } / 6-8^{\circ} \mathrm{C} \\
\end{array}$ & $\begin{array}{c}\text { warm, dry- } \\
\text { moderately humid } \\
/ 8-10^{\circ} \mathrm{C} \\
\end{array}$ & \\
\hline $\begin{array}{l}\text { Animals examined } \\
\text { Protozoa }\end{array}$ & 262 & 110 & 259 & 444 & 123 & 1198 \\
\hline Coccidia oocysts & $72 / 27.5$ & $24 / 21.8$ & $71 / 27.4$ & $98 / 22.1$ & $38 / 30.9$ & $\begin{array}{c}335 / 28.0 \\
(0.25-0.31)\end{array}$ \\
\hline \multicolumn{7}{|l|}{ Trematoda } \\
\hline Alaria alata & $11 / 4.2$ & $0 / 0$ & $1 / 0.4$ & $1 / 0.2$ & $1 / 0.8$ & $\begin{array}{c}14 / 1.2 \\
(0.01-0.02)\end{array}$ \\
\hline Opisthorchis felineus & $1 / 0.4$ & $0 / 0$ & $3 / 1.2$ & $0 / 0$ & $0 / 0$ & $\begin{array}{c}4 / 0.3 \\
(0.001-0.009)\end{array}$ \\
\hline \multicolumn{7}{|l|}{ Cestoda } \\
\hline Hymenolepis diminuta & $1 / 0.4$ & $0 / 0$ & $5 / 1.9$ & $0 / 0$ & $1 / 0.8$ & $\begin{array}{c}7 / 0.6 \\
(0.003-0.013)\end{array}$ \\
\hline Dipylidium caninum & $0 / 0$ & $0 / 0$ & $1 / 0.4$ & $4 / 0.9$ & $0 / 0$ & $\begin{array}{c}5 / 0.4 \\
(0.002-0.01)\end{array}$ \\
\hline Taeniidae & $21 / 8.0$ & $18 / 16.4$ & $40 / 15.4$ & $59 / 13.3$ & $7 / 6.5$ & $\begin{array}{c}146 / 12.2 \\
(0.10-0.14)\end{array}$ \\
\hline Mesocestoides spp. & $21 / 8.0$ & $10 / 9.1$ & $19 / 7.3$ & $17 / 3.8$ & $3 / 2.4$ & $\begin{array}{c}70 / 5.8 \\
(0.05-0.07)\end{array}$ \\
\hline \multicolumn{7}{|l|}{ Nematoda } \\
\hline Toxocara canis & $29 / 11.1$ & $12 / 10.9$ & $37 / 14.3$ & $56 / 12.6$ & $16 / 13.0$ & $\begin{array}{c}150 / 12.5 \\
(0.11-0.15)\end{array}$ \\
\hline Toxascaris leonina & $109 / 41.6$ & $18 / 16.4$ & $147 / 56.8$ & $169 / 38.1$ & $71 / 57.7$ & $\begin{array}{c}514 / 42.9 \\
(0.40-0.46)\end{array}$ \\
\hline Ancylostoma caninum & $51 / 19.5$ & $24 / 21.8$ & $82 / 31.7$ & $45 / 10.1$ & $16 / 13.0$ & $\begin{array}{c}217 / 18.1 \\
(0.16-0.20)\end{array}$ \\
\hline Uncinaria stenocephala & $13 / 5.0$ & $8 / 7.3$ & $30 / 11.6$ & $21 / 4.7$ & $11 / 8.9$ & $\begin{array}{c}83 / 6.9 \\
(0.06-0.09)\end{array}$ \\
\hline Strongyloides spp. & $1 / 0.4$ & $7 / 6.4$ & $8 / 3.1$ & $2 / 0.5$ & $1 / 0.8$ & $\begin{array}{c}19 / 1.6 \\
(0.01-0.02)\end{array}$ \\
\hline Spirocerca lupi & $1 / 0.4$ & $4 / 3.6$ & $4 / 1.5$ & $2 / 0.5$ & $0 / 0$ & $\begin{array}{c}11 / 0.9 \\
(0.005-0.017)\end{array}$ \\
\hline Physaloptera rara & $3 / 1.2$ & $0 / 0$ & $0 / 0$ & $9 / 2.0$ & $1 / 0.8$ & $\begin{array}{c}13 / 1.1 \\
(0.006-0.013)\end{array}$ \\
\hline Trichuris vulpis & $63 / 24.1$ & $39 / 35.5$ & $110 / 42.5$ & $148 / 33.3$ & $41 / 33.3$ & $\begin{array}{c}401 / 33.5 \\
(0.31-0.36)\end{array}$ \\
\hline Capillaria spp. & $36 / 13.7$ & $26 / 23.6$ & $98 / 37.8$ & $88 / 19.8$ & $20 / 16.3$ & $\begin{array}{c}268 / 22.4 \\
(0.20-0.25)\end{array}$ \\
\hline
\end{tabular}

Larvae of Trichinella spp. were recovered from the muscles of 485 of 4669 red foxes $(10.4 \%)$. Prevalence increased from $4.9 \%$ in 2000 to $13.0 \%$ in $2005 / 2006$, with a culmination in years 2003 and 2004 (13.3\%). The highest prevalence of infection was recorded in the Eastern and Central Slovakia (Košice region - 17.6 \%; Prešov region 14.8 \%; Banská Bystrica region - $12.4 \%$ (Table 1). No foxes collected in the south-western part of Slovakia (Bratislava, Trnava, Nitra) at the beginning of the study in 2000 harboured larvae of Trichinella spp. However, commencing in 2001 there was an increasing prevalence of infection in these areas. A significant increase in prevalence was observed in north-western regions (Trenčín, Žilina); there were no infected animals in $2000-2001$ but an increased percentage of infected foxes was observed in 2005 and 2006 ( $15.4 \%$ and $14.1 \%$, respectively). The larval burden in 452 infected foxes varied from 0.06 - 283 larvae per gram (lpg) of muscle tissue with a mean value of $8.8 \mathrm{lpg}$. Intensity of infection was highest in regions with the highest prevalence (Banská Bystrica - 9.38 lpg; Košice - 8.63 lpg; and Prešov - $10.1 \mathrm{lpg}$ ). Trichinellosis was most prevalent in localities with altitudes of $200-400 \mathrm{~m}$ above sea level (a.s.l.) and in territories with a high pressure from anthropogenic stress. Infected foxes also inhabited localities with altitudes of $400-600 \mathrm{~m}$ a.s.l.

A total of 393 isolates of larvae of Trichinella spp. were genotypically characterised by a multiplex PCR protocol. Trichinella britovi was the most important etiological agent of sylvatic trichinellosis in almost the entire Slovak territory. Up to $98.8 \%$ of infected foxes harboured T. britovi. Trichinella spiralis was detected in two foxes collected in the Prešov region. Two individuals from eastern Slovakia harboured a mixed infection with $T$. spiralis and T. britovi.

Coccidian oocysts or eggs of parasitic helminths were found in the faeces of 998 (83.3\%) of 1198 animals examined by a faecal flotation method. Coccidian oocysts were present in $28.0 \%$ of the red foxes examined, with the highest prevalence $(30.9 \%)$ in the southeastern region of Košice (Table 2). 
Fifteen helminth taxa were identified, including two trematode, four cestode and nine nematode species. Trematodes were found only sporadically and/or only in certain regions. In the class Cestoda, taeniidae eggs were recorded most frequently $(12.2 \%)$ in foxes, with the highest prevalence $(16.4 \%)$ in the northern Žilina region. One spurious cestode species, Hymenolepis diminuta, was found in eight foxes, with total prevalence $0.6 \%$. Toxascaris leonina was the most common nematode species found in the present survey and was recorded in $42.9 \%$ of red foxes, followed by Trichuris vulpis (33.5\%), Capillaria spp. (22.4\%) and Ancylostoma caninum (18.1\%). Substantial differences in the prevalence of these species were evident between individual regions (Table 2). T. leonina was most prevalent in regions of Eastern and Central Slovakia; T. vulpis in central and northern regions. Toxocara canis was observed in all surveyed regions, at a lower prevalence compared with $T$. leonina. The highest prevalence of parasite propagational stages in faeces was recorded in the central part of Slovakia (Banská Bystrica region), the lowest prevalence in the north-east (Prešov region). Only $16.7 \%$ of fox faeces contained neither coccidian oocysts nor helminth eggs (Table 3). Infection with a single parasite species occurred in $27.5 \%$ of individuals and mixed infections with two to seven parasite species occurred in $55.8 \%$ of individuals. In one faecal sample, coccidian oocysts, taeniid eggs, and eggs of T. canis, T. leonina, A. caninum, $T$. vulpis and Capillaria spp. were found.

Table 3 Relation between the numer of parasite taxa found in red foxes and the prevalence at which these parasites occured

\begin{tabular}{lcc}
\hline $\begin{array}{l}\text { Number of parasite } \\
\text { elements identified } \\
\text { per sample }\end{array}$ & $\begin{array}{c}\text { Number } \\
\text { of foxes }\end{array}$ & $\begin{array}{c}\text { \% of total foxes } \\
\mathbf{( 9 5 \% ~ C I )}\end{array}$ \\
\hline None parasite taxa & 200 & $16.7(0.15-0.19)$ \\
One parasite taxa & 329 & $27.5(0.25-0.30)$ \\
Two parasite taxa & 316 & $26.4(0.24-0.29)$ \\
Three parasite taxa & 220 & $18.4(0.16-0.21)$ \\
Four parasite taxa & 108 & $9.0(0.07-0.11)$ \\
Five parasite taxa & 19 & $1.6(0.01-0.02)$ \\
Six parasite taxa & 5 & $0.4(0.002-0.01)$ \\
Seven parasite taxa & 1 & $0.1(0.000-0.005)$ \\
\hline
\end{tabular}

\section{Discussion}

As a part of biocenosis, the red fox is primarily a predator and in areas where it is distributed, naturally keeps the number of small mammals in check. This carnivore is also involved in maintenance and spread of several viral, bacterial and parasitic zoonotic diseases; potentially transmissible to domestic, farm and game animals, and also to humans (Sládek \& Mošanský, 1985). Of all the wild carnivore species occurring in the territory of Slovakia, the red fox harbors the most diverse helminth fauna (Mituch, 1962).

The overall prevalence of Echinococcus multilocularis during 2000-2006 was $31.1 \%$. The results of long-term monitoring refer to the occurrence of two endemic areas situated in northwestern (Žilina \& Trenčín region) and northeastern Slovakia (Prešov region) with the prevalence in several districts ranging between $40 \%$ and $\geq 60 \%$. These differences in prevalence between northern and southern parts of the country may involve factors such as fox population density, presence of intermediate hosts, and climatic conditions. A significant increase of the red fox population in the Slovak Republic was recorded after a successful programme of vaccination against rabies after 1996. Similar expansion of this canid species was registered in Poland, where an antirabies campaign started in 1993. The fox population in Poland increased from 67000 in 1995 to over 200000 in 2006 (Borecka et al., 2008). The population density is estimated at 270 foxes per 1000 $\mathrm{km}^{2}$ and they are distributed throughout the entire territory (Letková et al., 2001). Results of our long-term monitoring provide evidence that climatic conditions in areas where $E$. multilocularis is endemic differ significantly from those in other parts of the country and significantly influence both prevalence and mean worm burden of E. multilocularis in red foxes. Low mean annual air temperature, high annual precipitations, low mean annual temperature of soil surface and high humidity of the soil are characteristic of northern Slovakia. Cold and moist environments may be key factors in the survival of tapeworm eggs which are very sensitive to desiccation and high temperatures (Veit et al., 1995). Within the similar study provided by Di Cerbo et al. in north-eastern Italy (2008), cestodes were more abundant in altitudes over $1000 \mathrm{~m}$ a.s.l. where small mammals, the intermediate host, are more prevalent in the fox diet. Our recent analyses also showed a significant correlation between prevalence of this tapeworm and population density of small mammals (Miterpáková et al., 2006). However, also the first 10 autochthonous cases of human alveolar echinococcosis were diagnosed in patients lived in endemic regions with the highest prevalence of the parasite in foxes (Kinčeková et al., 2006; 2008).

Trichinellosis among foxes was widespread across Slovakia and the prevalence in red foxes increased from $4.9 \%$ in 2000 up to $13.0 \%$ in $2005 / 06$. Our findings in 2000 revealed the presence of a sylvatic cycle exclusively in endemic regions of Košice, Prešov, Banská Bystrica and the eastern part of the Nitra region. No infected foxes were collected at the beginning of the survey in the western part of Slovakia. A different epidemiological picture has emerged since 2001, with an increase in the prevalence of infected foxes in the Danubian region (Komárno district) an area considered for decades to be free of Trichinella. In the same district of the Nitra region, a human outbreak was recorded in 2001 (Dubinský et al., 2001). Infected foxes were also found in the regions of Trenčín and Bratislava near the Czech Republic where, in 2001 after 50 years of absence of trichinellosis, infected wild boars were found in the Moravian territory (Pavlíčková \& Koudela, 2004). The question arises whether this spread of trichinellosis is associated with the spread of their host, the red fox, caused by a dense fox population from the east of 
Slovakia to the Czech Republic, or is it associated with transboundary transmission from Poland and the Czech Republic? In Poland, $5.7 \%$ of foxes were found to be positive for trichinellosis in southern parts of the country (Cabaj et al., 2000). Infected foxes were captured primarily at altitudes ranging from $200-400 \mathrm{~m}$ a.s.1., in areas predominated by arable land, broad-leaved forests and localities with $30-50 \%$ dispersed natural vegetation (forest tufts, groups of trees and shrubs in boundaries). Our study revealed that intensity of infection was highest in endemic areas of eastern and central Slovakia (mean infection intensity $8.63-10.1 \mathrm{lpg}$ ) in contrast to southern and western regions where the mean intensity of infection varied from 1.5 to $4.15 \mathrm{lpg}$. Infection pressure in endemic areas may be higher than in new foci of vulpine trichinellosis. It is generally considered that sylvatic trichinellosis occurs in carnivores with cannibalistic and scavenger behaviour. Higher population density results in intense competition for food and thus more scavenging and cannibalism, the primary routes of Trichinella transmission (Pozio et al., 1996). In some countries of the European Union, cannibalism among foxes and landscape characteristics (mountains vs. lowlands) have been considered key factors in maintaining this parasite in nature (Rossi et al., 1992; Pozio et al., 1996). Lowlands are more likely to be Trichinella-free because of the greater impact of humans on the environment (Oivanen \& Oksanen, 1994). Herein, we report the presence of two Trichinella species in the Slovak Republic, which are identified using molecular analysis. Our findings that Trichinella britovi was the predominant species in the Slovak territory with $98.8 \%$ of animals infected with this species were consistent with observations that $T$. britovi is the predominant species in red fox populations in Europe (Pozio et al., 1996). In the Slovak Republic, T. spiralis was detected only sporadically, probably as a residuum of its former presence in a domestic cycle. Mixed infection with $T$. spiralis and $T$. britovi found in fox is not surprising because mixed infections have been detected previously in wildlife (Oivanen et al., 2002; Malakauskas et al., 2002; Cabaj et al., 2004).

A total of 1198 vulpine faecal samples were examined and coccidian oocysts and helminth eggs were detected in 998 animals, a prevalence of $83.3 \%$. Most of the parasites found are cosmopolitan in foxes in Europe; however, the prevalence of each species varies between individual countries and even between regions in a country. This variability may be explained by different climatic conditions, landscape patterns and usage, and host population density. Also the presence of suitable intermediate hosts plays an important role in the circulation of parasites with indirect developmental cycles.

Protozoa were represented in red fox faeces by coccidian oocysts which could not be sporulated because of freezing and consequently were not able to be identified to species. after deep - freezing the faeces samples.

Eggs of Trematoda were recorded only sporadically and represented by two species; Alaria alata and Opisthorchis felineus with prevalences of $1.2 \%$ and $0.3 \%$, respectively. Surprisingly, O. felineus was an endemic species in eastern and southern Slovakia in 1950 (Jurášek \& Dubinský, 1993).

Cestoda were most frequently represented by the family Taeniidae with an overall prevalence of $12.2 \%$. Several species of taeniid cestodes occur in red foxes however, they cannot be differentiated on the basis of egg morphology. Coprological examination resulted in an overall prevalence of Mesocestoides spp. in foxes of $5.8 \%$, while necropsy resulted in a prevalence of $58.6 \%$. The eggs of other tapeworm species (Dipylidium caninum and Hymenolepis diminuta) were observed only sporadically in some areas. However, $H$. diminuta, a tapeworm infecting rats, mice and humans, may be considered a spurious infection transferred from the pray of the foxes (Borgsteede, 1984; Pfieffer et al., 1997).

Nematoda were the most dominant class recovered in faeces of red foxes with nine genera represented (Toxocara canis, Toxascaris leonina, Ancylostoma caninum, Uncinaria stenocephala, Strongyloides spp., Spirocerca lupi, Physaloptera spp., Trichuris vulpis, and Capillaria spp.). The most abundant was $T$. leonina with an overall prevalence of $42.9 \%$. The other member of Ascarididae $-T$. canis, was found only in $12.5 \%$ of red foxes examined. Most European studies report higher prevalence of $T$. canis than T. leonina (Richards et al., 1995; Saeed \& Kapel, 2001; Smith et al., 2003). Another frequently occurring species from the class Nematoda was $T$. vulpis with mean prevalence of $33.5 \%$ and highest prevalence in central Slovakia (42.5\%). A. caninum was present in $18.1 \%$ and $U$. stenocephala in $6.9 \%$ of red foxes investigated, with the highest prevalence in areas with a high proportion of cultivated soil, which concur with the findings of Richards et al. (1995) and Gortázar et al. (1998) observed higher prevalence of $A$. caninum infection in areas with irrigated soil. Strongyloides stercoralis was identified in $1.6 \%$ of foxes examined and prevalence was highest in north-western Slovakia (6.4\%). The eggs and larvae of this species are very sensitive to drying and require high air and soil humidity, climatic conditions characteristic of this part of Slovakia. The least prevalent nematode species was Spirocerca lupi found in 11 samples with the highest positivity $(3.6 \%)$ in Žilina region bordering on Poland. The first record of $S$. lupi from Poland date 2005, when the parasite was detected in $2.3 \%$ of 86 wolf scats investigated (Szczesna \& Popiolek, 2007).

Generally, central parts of Slovakia, where the highest prevalence of parasites was recorded are characterized by warm-moderately cool and moderately humid climate, with $8-9{ }^{\circ} \mathrm{C}$ mean annual air temperature, $600-900 \mathrm{~mm}$ of mean annual precipitation and slightly moist-moist soil moisture regime with mean annual temperature of active soil surface ranging between $8-10{ }^{\circ} \mathrm{C}$. In contrast, the lowest prevalence of parasites was found in north-eastern Slovakia characterized by moderately warm or moderately cold and humid climate with mean annual air temperatures 6 and $8{ }^{\circ} \mathrm{C}, 600$ to $900 \mathrm{~mm}$ mean annual precipitation and 
slightly moist or moist soil regime with mean annual temperature of active soil surface $5-7^{\circ} \mathrm{C}$. These two regions differ mainly in the mean annual air temperature and temperature of active soil surface. Higher temperatures in region on central Slovakia together with more humid climate and moist soil moisture regime may be factors influencing better survival of parasite developmental stages. Our long-term parasitological examination of red foxes highlighted the fact that these wild carnivores play a significant role in environmental contamination with parasites and may contribute significantly to the spread of parasitic zoonoses. Climatic changes, landscape changes, increasing numbers of red foxes and the process of colonization of new areas by these wild animals may play important roles in the structuring of parasite communities and provides opportunities for increased exposure to parasitic infection.

\section{Acknowledgements}

We would like to thank the State Veterinary and Food Institutes of the Slovak Republic for sample collection. The investigation was supported by the Science Grant Agency VEGA 2/0145/09.

\section{References}

BorgsteEde, F. H. M. (1984): Helminth parasites of wild foxes (Vulpes vulpes L.) in the Netherlands. Parasitol. Res., 70: $281-285$

Cabaj, W., Pozio, E., Moskwa, B., Malczewski, A. (2000): Trichinella britovi and T. spiralis in red foxes (Vulpes vulpes) in Poland. Acta Parasitol., 45: 340 - 344

BoreckA, A., GAwOR, J., MALCZEWSKA, M., MALECZEWSKI, A. (2008): Occurrence of Echinococcus multilocularis in red foxes (Vulpes vulpes) in southern Poland. Helminthologia, 45: $24-27$

Cabaj, W., Moskwa, B., Pastusiak, K., Bien, J., MALCZEWSKI, A. (2004). Trichinellosis in wild and domestic animals in Poland. In Abstract Book of XI ${ }^{\text {th }}$ International Conference on Trichinellosis, Abstr. No. 68. DI Cerbo, A. R., Manfredi, M. T., Bregoli, M., Ferro Milone, N., CovA, M. (2008): Wild carnivores as source of zoonotic helminths in north-eastern Italy. Helminthologia, 45: $13-19$

DubinskÝ, P., Svobodová, V., TurČEKOVÁ, L., LiterÁK, I., MARTíneK, K., ReITEROVÁ, K., KOLÁŘOVÁ, L., KLIMEŠ, J., MrLíK, V. (1999): Echinococcus multilocularis in Slovak Republic: The first record in red foxes (Vulpes vulpes). Helminthologia, 36: 105 - 110

DUBINSKÝ, P., ŠTEFANČíKOVÁ, A., KINČEKOVÁ, J., ONDRISKA, F. (2001): Trichinellosis in the Slovak Republic. Parasite, 8: 100 - 102

Gortázar, Ch., Villafuerte, R., Lucientes, J., Luco, D. F. (1998): Habitat related differences in helminth parasites of red foxes in the Ebro valley. Vet. Parasitol., 80: 75 $-81$

JuRÁŠEK, V., DuBInskÝ, P. (Eds.) (1993): Veterinary Parasitology. Príroda, Bratislava, Slovakia (In Slovak)
KAPEL, C. M. O., GAMBle, H. R. (2000): Infectivity, persistence, and antibody response to domestic and sylvatic Trichinella spp. in experimentally infected pigs. Int. J. Parasitol., 30: 215 - 221

KinČeKovÁ, J., HrČKová, G., Auer, H., Szilágyiová, M., HudačKová, J., Stanislayová, M., PolÁČeK, H., ŠImeKOVÁ, K. (2006): Clinical and serological study of human alveolar echinococcosis in Slovakia in relation to the outcome of chemotherapy. Helminthologia, 42: 213 219

KinČeková, J., HrČKovÁ, G., Bober, J., Vrzgula, A., SzABADOŠOVÁ, V., BOHUŠ, P., ZACHAR, M. (2008): A rare case of alveolar echinococcosis in a 14-year-old child. Helminthologia, 45: 28-31

Letková, V., Csizsmárová, G., Goldová, M., Lazar, P., ČURLÍK, J., KoŠUTH, P. (2001): Parasitoses of Red fox (Vulpes vulpes L., 1758) in East Slovak Region. Folia Venatoria, $30-31: 225-228$

MALAKAUSKAS, A. (2002): Molecular epidemiology of Trichinella spp. in Lithuania. Ph.D. Thesis. Copenhagen, Denmark, pp. 135

MiterpákOVÁ, M., DubinskÝ, P., ReiterovÁ, K., StAnKo, M. (2006): Climate and environmental factors influencing Echinococcus multilocularis occurrence in the Slovak Republic. Ann. Agric. Environ. Med., 13: 125 - 242 Mituch, J. (1962): Contribution to the knowledge of the helminthofauna in the red fox (Vulpes vulpes crucigera L.) in Slovakia. Vet. med. (Praha), 7: $227-238$

Mituch, J. (1964): On the helminth fauna of Felidae in Slovakia. Helminthologia, 5: 125 - 134

MituCH, J. (1972): The helminthofauna of Carnivora in Slovakia and Czechoslovakia. Folia Venatoria, 2: 161172.

Oivanen, L., OKSANEN, A. (1994): Trichinellosis in domestic swine and wildlife in Finland. In: CAMPBELL, W. C., PozIO, E., Bruschi, F. (Eds) Trichinellosis. Instituto Superiore di Sanità Press: Rome, Italy, pp. 569 - 574

Oivanen, L., Kapel, C. M. O., Pozio, E., La Rosa, G. (2002): Associations between Trichinella species and host species in Finland. J. Parasitol., 88: $84-88$

PAVlíčKovÁ, Z., Koudela, B. (2004): The occurrence of animal trichinellosis in the Czech Republic. In Proceedings of Czech and Slovak Parasitological Days, p. 59

Pfieffer, F., Kuschfeldt, S., Stoye, M. (1997): Helminth fauna of the red fox (Vulpes vulpes LINNE 1758) in south Sachsen-Anhalt-1: Cestodes. Dtsch. Tierarztl. Wochenschr., 104: 445 - 448

PozIO, E., LA RosA, G. (2003): PCR-derived methods for the identification of trichinella parasites from animal and human samples. Methods Mol. Biol., 216: 299 - 309

Pozio, E., La Rosa, G., Serrano, F. J., BArrat, J., Rossi, L. (1996): Environmental and human influence on the ecology of Trichinella spiralis and Trichinella britovi in Western Europe. Parasitology, 113: 527 - 533

ProkopiČ, J. (1958): Helminthfauna of Carnivores in Czechoslovakia. Čsl. Parazitol., 5: 157 - 164

ProKopič, J. (1965): Helminthfauna of Carnivores in Czechoslovakia. Čsl. Parazitol., 12: 207 - 226 (In Czech) 
Raoul, F., Deplazes, P., Nonaka, N., Piarroux, R., Vuitton, D. A., Giraudoux, P. (2001): Assessment of the epidemiological status of Echinococcus multilocularis in foxes in France using ELISA coprotests on fox faeces collected in the field. Int. J. Parasitol., 31: $1579-1588$ Richards, D. T., HARris, S., LEWIS, J. W. (1995): Epidemiological studies on intestinal helminth parasites of rural and urban red foxes (Vulpes vulpes) in the United Kingdom. Vet. Parasitol., 59: 39 - 51

Rossi, L., Pozio, E., Mignone, W., Ercolini, C., Dini, V. (1992): Epidemiology of sylvatic trichinellosis in Northwestern Italy. Rev. - Off. Int. Epizoot., 11 : 1039 - 1046

SAEED, I., KAPEL, C. M. O. (2001): Echinococcus multilocularis in Scandinavia: Results of helminthological studies of Danish red foxes. In Abstract Book of XX. International Congress of Hydatidology, Kusadasi, Turkey p. 245

SlÁDEK, J., MoŠAnSKÝ, A. (1985): Mammals around us. Osveta (Ed.), Martin, 256 pp. (In Slovak)

Sloss, M. W. (1970): Veterinary clinical parasitology. The Iowa State University Press: USA

Smith, G. C., Gangadharan, B., TAYlor, Z., Laurenson, M. K., Bradshaw, H., Hide, G., Hughes, J. M., DinKel, A., RoMig, T. (2003): Prevalence of zoonotic important parasites in the red fox (Vulpes vulpes) in Great Britain. Vet. Parasitol., 118: 133 - 142
Statistical Yearbook of the Slovak Republic 1993. (1994): VEDA, Bratislava, Slovakia

StATISTICAL YEARBOOK OF THE SlOVAK RePUbliC 1996. (1997): VEDA, Bratislava, Slovakia

SzCZESNA, M., PoPIOLEK, M. (2007): The first record of Spirocerca lupi (Rudolphi, 1809) (Spirocercidae, Nematoda) from Poland based on faecal analysis of wolf (Canis lupus L.). Helminthologia, 44: 230 - 232

ŠVrČEK, Š., ZÁVADOVÁ, J., MAĎAR, M., ONDREJKA, R., SÜliovÁ, J., BENÍŠEK, Z., ONDREJKOVÁ, A., FrANKA, R. (2000): Recent results of research and development achieved at the Joint Rabiologic Laboratory of the Research Institute of Veterinary Medicine and the University of Veterinary Medicine in Košice. Slov. Vet. Čas., 25: $294-$ 296

THOMPSON R. C. A. (1995). Biology and systematics of Echinococcus. In: THOMson, R. C. A., LYMBERY, A. (Eds) Echinococcus and Hydatid Disease. CAB International: Wallingford, Oxon, pp. $1-50$

Veit, P., Bilger, B., Schod, V., SchÄFER, J. (1995): Influence of environmental factors on the infectivity of Echinococcus multilocularis eggs. Parasitology, 110: 79 - 86 Vogel, H. (1957): Echinococcus multilocularis in south Germany. Z. Tropenmed. Parasitol., 8: $404-454$ 